\title{
MACC
}

\section{Kanabis dan Penggunaannya dalam Terapi Nyeri Kronis}

\author{
Madonna Damayanthie Datu ${ }^{1 *}$, Jokevin Prasetyadhi ${ }^{1}$ \\ 1. Departemen Anestesiologi, Terapi Intensif, dan Manajemen Nyeri, Fakultas \\ Kedokteran, Universitas Hasanuddin, Makassar, Indonesia
}

*penulis korespondensi

DOI: 10.55497/majanestcricar.v39i2.203

\begin{abstract}
ABSTRAK
Nyeri kronis adalah "nyeri tanpa nilai biologis nyata" yang bertahan hingga lebih dari 3 bulan. Pasien yang menderita nyeri kronis sering kali memiliki penyakit biologis yang tidak dapat dipisahkan dari faktor kognitif, afektif, perilaku, dan sosial sehingga memiliki dampak negatif terhadap kualitas hidup. Banyak penelitian telah dilakukan untuk menemukan cara penanganan nyeri yang adekuat dengan efek samping seminimal mungkin. Bunga dari tanaman kanabis (Cannabis sativa) telah mulai digunakan sebagai analgesia nyeri kronis, namun efikasinya masih kontroversial. Konstituen utama kanabis seperti delta 9-tetrahydrocannabinol (THC), cannabidiol (CBD), dan cannabinol (CBN) telah diketahui memiliki kontribusi terhadap mekanisme mengurangi nyeri. Sediaan kanabis bervariasi dengan rasio THC/CBD yang berbeda-beda, disertai dengan potensi efek samping pada berbagai sistem organ. Rute pemberian yang paling umum adalah inhalasi dan oral. Walaupun kanabis dapat digunakan sebagai salah satu penanganan nyeri kronis, namun dalam penggunaannya dapat berpotensi disalahgunakan hingga menyebabkan efek psikotik. Oleh karena itu, diperlukan pemahaman yang baik mengenai farmakologi kanabis agar dapat digunakan sebagai alternatif pengobatan nyeri kronis.
\end{abstract}

Kata Kunci: analgesia, farmakologi, kanabis, nyeri kronis 


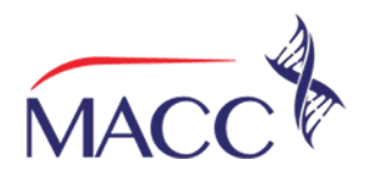

\title{
Cannabis and Its Use in Chronic Pain Management
}

\author{
Madonna Damayanthie Datu ${ }^{1 *}$, Jokevin Prasetyadhi ${ }^{1}$
}

1. Department of Anesthesiology, Intensive Care, and Pain Management, Faculty of Medicine, Universitas Hasanuddin, Makassar, Indonesia

*corresponding author

\begin{abstract}
Chronic pain is defined as "pain without actual biological damage" that has persisted more than 3 months. Patient with chronic pain often have biological diseases that affect cognitive, affective, behavioral, and social factors which cause a negative impact on the quality of life. Several studies have been conducted to find an adequate pain treatment with minimal side effects. Cannabis is the flower of the cannabis plant (Cannabis sativa) which is currently being used for medical purposes. However, the efficacy of cannabis, especially as an analgesia agent, is still controversial. The main constituents that contribute cannabis to reduce pain are delta 9-tetrahydrocannabinol (THC), cannabidiol (CBD), and cannabinol (CBN). Cannabis dosage varies with different $T H C / C B D$ ratios, as well as potential side effects in various organ systems. Common administration routes are inhalation and oral. In addition, there is potential for cannabis abuse which can lead to cannabis use disorders or even psychotic effects. Therefore, an understanding of cannabis pharmacology is needed in order to use cannabis as an alternative treatment for chronic pain.
\end{abstract}

Keywords: analgesic, cannabis, chronic pain, pharmacology 


\section{PENDAHULUAN}

Pada umumnya, pasien kanker dapat mengalami nyeri kronis akibat keterlibatan tumor ataupun efek samping dari pengobatan kanker. Nyeri yang dialami tersebut dapat berdampak negatif terhadap aspek fisik, fungsional, maupun emosional, sehingga diperlukan penanganan nyeri yang adekuat untuk memperbaiki kualitas hidup pasien. Terapi nyeri kronis pada kanker saat ini bertumpu pada pemberian opioid, namun opioid dapat menimbulkan beberapa efek samping ringan hingga berat. Hal tersebut menyebabkan perlunya dilakukan penelitian lain untuk menemukan terapi alternatif. ${ }^{1}$

Kanabismenghasilkansenyawaalamiyangdikenal sebagai kanabinoid, yaitu senyawa endogen dan eksogen yang berikatan dengan reseptor inhibisi kanabinoid spesifik yang mengurangi jumlah neurotransmiter. ${ }^{1,2}$ Konstituen utama dari kanabis adalah delta 9-tetrahydrocannabinol (THC), cannabidiol (CBD), dan cannabinol (CBN). Dalam penggunaannya sebagai obat, kanabis tersedia dalam berbagai rasio $\mathrm{THC} / \mathrm{CBD}$, dan jenis sediaan. Penggunaan kanabis dengan tujuan medis yang bervariasi telah digunakan di seluruh dunia. Kanabis telah dilaporkan bermanfaat dalam berbagai kondisi, mulai dari nyeri sendi, spasme otot, hingga kondisi seperti asam urat dan malaria.3 Meskipun kanabis telah digunakan pada berbagai kondisi medis, namun efikasinya sebagai analgesia masih kontroversial. ${ }^{4-6}$

Penelitian mengenai penggunaan kanabis seringkali terhambat karena perdebatan legalitasnya. ${ }^{7}$ Peraturan hukum dari satu negara ke negara lain berbeda karena kurangnya studi yang meneliti efikasi kanabis untuk penyakit tertentu. Menurut Undang-Undang Nomor 35 tahun 2009 tentang Narkotika di Indonesia, tanaman genus cannabis dan semua bagian dari tanaman termasuk biji, buah, jerami, hasil olahan tanaman kanabis atau bagian tanaman kanabis (termasuk damar kanabis dan hasis) dimasukkan ke dalam daftar narkotika golongan I (kelompok zat dengan pengendalian paling ketat, penggunaan sangat dibatasi, hanya untuk tujuan penelitian). ${ }^{8}$

Semua negara konsisten menyatakan bahwa nyeri kronis merupakan salah satu indikasi dari penggunaan kanabis, namun banyak pasien yang menggunakan kanabis tanpa seizin dokter.
Hal tersebut menyebabkan penyalahgunaan kanabis dan menimbulkan efek samping. Maka dari itu, para klinisi memerlukan pemahaman yang baik mengenai penggunaan kanabis dan efek samping yang dapat ditimbulkannya guna mencapai pelayanan yang optimal dalam penanganan nyeri kronis. ${ }^{7}$

\section{TINJAUAN PUSTAKA}

\section{Patofisiologi Nyeri Kronis}

International Association for the Study of Pain (IASP) mendefinisikan nyeri sebagai "pengalaman sensorik dan emosional yang tidak menyenangkan terkait dengan kerusakan jaringan aktual atau potensial" dan nyeri kronis sebagai "nyeri tanpa nilai biologis nyata yang telah bertahan melampaui waktu penyembuhan jaringan normal" yang biasanya terjadi lebih dari 3 bulan. Pasien yang menderita nyeri kronis sering kali memiliki penyakit biologis yang tidak dapat dipisahkan dari faktor kognitif, afektif, perilaku, dan sosial sehingga memiliki dampak negatif terhadap kualitas hidup. ${ }^{9}$

Nyeri kronis dapat diklasifikasikan sebagai nosiseptif dan neuropatik. Nyeri nosiseptif merupakan hasil dari aktivasi reseptor yang sensitif terhadap stimulus berbahaya. Paparan stimulus yang berkepanjangan atau intens (misalnya, mediator kimiayang dilepaskan selama inflamasi) dapat meningkatkan sensitivitas serabut saraf nosiseptif. Proses ini disebut sensitisasi perifer. Sensitisasi perifer terjadi akibat perubahan ambang aktivasi nosiseptor dan peningkatan regulasi voltage-gated sodium channels, yang dapat meningkatkan aktivitas potensial aksi dan pelepasan transmiter di dorsal horn medula spinalis, yaitu tempat proses informasi somatosensori. Saraf-saraf dorsal horn mengalami peningkatan eksitabilitas terhadap aktivitas potensial aksi. Proses ini disebut sensitisasi sentral. ${ }^{10}$

Sensitisasi sentral adalah keadaan dimana sistem saraf pusat "memperbesar" input sensoris dari berbagai sistem organ. Peningkatan respons terhadap sensitisasi menyebabkan plastisitas saraf sehingga meningkatkan sensitivitasnya terhadap stimulus. Hipersensitivitas dapat memengaruhi semua sistem organ. ${ }^{11}$ Peningkatan depolarisasi menyebabkan rekrutmen reseptor glutamat tipe $N$-methyl-D- 
aspartate (NMDA). Aktivasi NMDA dan reseptor neuropeptida meningkatkan kadar kalsium intraseluler sehingga menyebabkan perubahan jalur pengiriman sinyal dan ekspresi gen. Perubahan-perubahan ini akan mengakibatkan perubahan jangka panjang pada aktivitas sirkuit nosiseptif. Sensitisasi sentral juga menyebabkan respons yang berlebihan terhadap stimulus yang menyakitkan (hiperalgesia) dan stimulus yang tidak menyakitkan (alodinia). Beberapa penelitian menunjukkan hipersensitivitas nyeri dapat menyebabkan perubahan struktural di otak. $^{10}$

Berbeda dengan nyeri nosiseptif, pada nyeri neuropatik, lesi di saraf perifer dapat membangkitkan aktivitas ektopik serabut saraf. Sel-sel imun bawaan juga aktif di lokasi lesi, di dorsal root ganglion, dan di dorsal horn medula spinalis. Mikroglia di dorsal horn melepaskan mediator kimia yang memodulasi aktivitas saraf di sekitarnya. Salah satu mediator kimia tersebut adalah brain-derived neurotrophic factor (BDNF) yang bekerja mengurangi efek inhibitorik dari $\gamma$-aminobutyric acid (GABA) dan glisin. Disinhibisi menyebabkan terbukanya jalur polisinaptik di dorsal horn sehingga aktivitas abnormal dari saraf lesi akan semakin meningkat. Hal tersebut menyebabkan terjadinya sensitisasi sentral. ${ }^{10}$

\section{Farmakologi Kanabis}

Menurut Single Convention on Narcotic Drugs tahun 1961, kanabis adalah bunga dari tanaman kanabis (Cannabis sativa) yang resinnya belum diekstraksi. ${ }^{1}$ Tanaman kanabis dapat menghasilkan setidaknya 144 senyawa alami yang dikenal sebagai kanabinoid. Kanabinoid yang paling banyak diteliti adalah Delta 9-tetrahydrocannabinol (THC) dan cannabidiol (CBD). ${ }^{12}$ Konstituen utama kanabis tersebut, terutama THC, memiliki efek intoksikasi. ${ }^{1}$

\section{Bentuk Kimia}

Tetrahydrocannabinol adalah senyawa psikoaktif utama di kanabis, diikuti CBD dan senyawa nonpsikoaktif. THC adalah komponen psikoaktif utama pada kanabis. THC bekerja sebagai agonis parsial lemah pada reseptor CB1 dan CB2, yang memiliki efek terhadap nyeri, nafsu makan, pencernaan, emosi dan proses berpikir yang dimediasi melalui sistem endocannabinoid.
Sistem Endocannabinoid mengatur homeostatis dari berbagai fungsi fisiologis. THC dapat menyebabkan efek samping psikoaktif, tergantung pada dosis dan toleransi pasien. ${ }^{13}$

CBD hanya memiliki afinitas minimal pada reseptor $\mathrm{CB} 1$ dan $\mathrm{CB} 2$. CBD merupakan modulator alosterik negatif dari $\mathrm{CB} 1$, dengan efek farmakologis pada berbagai sistem reseptor lainnya termasuk TRPV1, 5-HT1A, adenosin A2A dan mekanisme non-reseptor. ${ }^{13}$

Pada umumnya, konsentrasi THC lebih tinggi dibandingkan CBD. Seiring dengan penelitian lebih lanjut, komposisi kimia dari Cannabis sativa masih terus mengalami perubahan dengan ditemukannya konstituen non-kanabinoid dan kanabinoid baru. ${ }^{4-6}$

\section{Rute Pemberian}

Rute pemberian kanabis yang paling umum adalah inhalasi merokok, vaporisasi maupun oral. Metode pemberian dapat memengaruhi onset, intensitas, durasi efek psikoaktif (efek pada sistem organ dan potensi kecanduan) dan efek samping yang terkait dengan penggunaan kanabis. Konstituen psikoaktif primer (D9THC) ditransfer dari paru-paru ke darah dengan cepat selama merokok. ${ }^{14}$ Vaporisasi memberikan efek yang serupa dengan merokok sekaligus mengurangi paparan kombusio dan kemungkinan karsinogen. Inhalasi THC menyebabkan konsentrasi plasma mencapai maksimum dalam beberapa menit dan efek psikotropika dalam hitungan detik hingga menit. Pada pemberian oral, onset efek psikotropika timbul lebih lama dengan durasi lebih lama tergantung pada dosis (Tabel 1). ${ }^{15}$

\section{Farmakokinetik}

THC adalah agonis parsial terhadap reseptor CB1 dan CB2 dalam sistem kanabinoid endogen yang memberikan efek modulasi psikoaktif dan nyeri. CBD memiliki afinitas yang relatif rendah di reseptor ini dan dapat menghambat THC dengan berikatan pada reseptor CB1. CBD juga berikatan dengan reseptor non-kanabinoid lainnya (Tabel 2). ${ }^{16}$

THC dan CBD memiliki mekanisme kerja yang berlawanan pada sistem endokanabinoid yang diekspresikan di sistem saraf pusat dan perifer. Pada uji klinis skizofrenia, CBD meningkatkan 
Tabel 1. Keuntungan dan Kerugian dari Berbagai Rute Pemberian Kanabis ${ }^{13}$

\begin{tabular}{|c|c|c|c|c|}
\hline & Merokok/vaporisasi & Oral & Oromukosal & Topikal \\
\hline Onset (menit) & $5-10$ & $60-180$ & $15-45$ & Bervariasi \\
\hline Durasi (jam) & $2-4$ & $6-8$ & $6-8$ & Bervariasi \\
\hline Keuntungan & $\begin{array}{lr}\text { Kerja cepat, } & \text { crantaat untuk } \\
\text { bermanfaat } & \text { gejala akut atau } \\
\text { episodik (mual/nyeri) }\end{array}$ & $\begin{array}{l}\text { Lebih nyaman, } \\
\text { bermanfaat untuk } \\
\text { penyakit atau gejala } \\
\text { kronis }\end{array}$ & $\begin{array}{l}\text { Sediaan farmasi } \\
\text { ( } \mathrm{n} \text { a b i x i m o I s ), } \\
\text { dengan efikasi dan } \\
\text { keamanan yang } \\
\text { telah terbukti }\end{array}$ & $\begin{array}{l}\text { Efek sistemik lebih } \\
\text { sedikit, efektif untuk } \\
\text { gejala lokal }\end{array}$ \\
\hline Kerugian & Dosis sulit dikendalikan & $\begin{array}{lr}\text { Titrasi } & \text { dosis } \\
\text { sulit } & \text { dikendasih } \\
\text { karena } & \text { onset } \\
\text { tertunda } & \end{array}$ & Biaya tinggi & $\begin{array}{l}\text { Hanya memiliki efek } \\
\text { lokal }\end{array}$ \\
\hline
\end{tabular}

kadar endokanabinoid plasma yang berkorelasi dengan perbaikan gejala. Ketika diberikan dengan THC, CBD dapat mengimbangi beberapa efek negatif dari THC seperti gangguan memori dan paranoia. CBD memiliki profil keamanan yang sangat baik dan dapat ditoleransi dengan baik, bahkan pada dosis tinggi. Dalam tinjauan sistematis dan meta-analisis, kanabinoid (terutama THC) dikaitkan dengan peningkatan tingkat disorientasi dan pusing hingga lima kali lipat bila dibandingkan dengan plasebo. ${ }^{17}$ Oleh karena itu, keseimbangan antara THC dan CBD dapat berkontribusi terhadap keamanan serta efek terapeutik kanabis.

\section{a. Absorpsi}

Kanabinoid yang diberikan melalui inhalasi menunjukkan farmakokinetik yang serupa dengan pemberian intravena. Setelah inhalasi, konsentrasi plasma puncak THC dan CBD tercapai dalam 3-10 menit dan konsentrasi maksimum lebih tinggi dari konsumsi oral. Bioavailabilitas THC setelah inhalasi berkisar 10-35\% karena adanya variabilitas (intra- dan intersubyek) dalam karakteristik inhalasi (jumlah, durasi dan interval inhalasi, waktu tahan napas, volume inhalasi), alat inhalasi, dan ukuran partikel yang dihirup. CBD inhalasi dilaporkan memiliki bioavailabilitas sistemik rata-rata $31 \%$ dan profil waktu konsentrasi plasma serupa dengan THC. Pemberian inhalasi atau oromukosal dilakukan untuk mengurangi first-pass metabolism ekstensif. ${ }^{18}$

Sediaan oromukosal Sativex ${ }^{\circledR}$ (nabiximols) oromucosal spray mengalami absorpsi yang cepat melalui mukosa oral sehingga berguna untuk mengurangi gejala dengan cepat. Hal tersebut menyebabkan konsentrasi obat plasma yang lebih tinggi dibandingkan pemberian oral, tetapi lebih rendah dibandingkan THC inhalasi. ${ }^{18}$ THC dan CBD bersifat lipofilik dan memiliki bioavailabilitas oral yang buruk (diperkirakan serendah 6\%). Sediaan THC oral memiliki tingkat absorpsi yang bervariasi dan menjalani firstpass metabolism ekstensif di hepar, sehingga menghasilkan konsentrasi THC plasma puncak yang lebih rendah dibandingkan inhalasi dan waktu yang lebih panjang (sekitar 120 menit) untuk mencapai konsentrasi puncak. Waktu konsentrasi plasma CBD oral serupa dengan THC oral. ${ }^{18}$ Berdasarkan profil tersebut, maka disimpulkan bahwa sediaan oral mungkin berguna untuk pasien yang memerlukan perbaikan gejala pada periode yang lebih panjang.

Pemberian kanabinoid secara transdermal memiliki kelemahan karena sifatnya yang hidrofobik menyebabkan keterbatasan obat berdifusi melewati lapisan kulit yang berair. Transportasi kulit yang efektif hanya dapat diperoleh dengan peningkatan permeabilitas. ${ }^{18}$

\section{b. Distribusi}

Kanabinoid menyebar dengan cepat ke wellvascularized organs (misalnya paru-paru, jantung, otak, hati) kemudian mengalami ekuilibrasi ke less vascularized tissue. Distribusi tersebut dapat dipengaruhi oleh ukuran dan komposisi tubuh serta kondisi penyakit yang memengaruhi permeabilitas sawar darahjaringan. ${ }^{18}$

Pada penggunaan jangka panjang, terjadi penumpukan kanabinoid di jaringan adiposa. Pelepasan dan redistribusi berikutnya (misalnya, 
penurunan berat badan) dapat mengakibatkan kanabinoid terus aktif selama beberapa minggu pasca pemberian. ${ }^{18}$

\section{c. Metabolisme}

Sebagian besar metabolisme THC terjadi di hepar melalui sitokrom P450 (CYP450) isozim CYP2C9, CYP2C19 dan CYP3A4. THC dimetabolisme menjadi 11-hydroxy-THC (11-OH-THC) dan 11-carboxy-THC (11-COOH-THC) yang mengalami glukuronidasi dan diekskresikan melalui feses dan urin. Metabolisme THC juga terjadi pada jaringan ekstra-hepar yang mengekspresikan CYP450, termasuk usus kecil dan otak. Metabolit 11-OH-THC memiliki aktivitas psikoaktif. THC lipofilik mampu melewati plasenta dan diekskresikan dalam ASI sehingga dapat menyebabkan toksisitas pada otak yang sedang berkembang. ${ }^{18}$

Metabolisme CBD juga terjadi di hepar, terutama oleh isozim CYP2C19, CYP3A4, CYP1A1, CYP1A2,
CYP2C9 dan CYP2D6. Setelah hidroksilasi menjadi 7-hydroxy cannabidiol (7-OH-CBD), terjadi metabolisme hepar lebih lanjut kemudian diekskresi di feses dan urin. Aktivitas farmakologis dari metabolit CBD di manusia masih belum diketahui secara pasti. ${ }^{18}$

\section{d. Eliminasi}

Perkiraan waktu paruh eliminasi THC bervariasi, dengan waktu paruh paling cepat sekitar 6 menit dan paling lama mencapai $22 \mathrm{jam}$. Hal tersebut dipengaruhi keseimbangan antara kompartemen penyimpanan lipid dan darah. Pengguna kanabis kronik memiliki waktu paruh eliminasi yang lebih lama karena terjadinya redistribusi dari kompartemen jaringan lemak. ${ }^{18}$

CBD memiliki waktu paruh eliminasi terminal yang panjang dengan rata-rata waktu paruh setelah pemberian inhalasi $31 \pm 4 \mathrm{jam}$. Pemberian CBD oral harian memiliki waktu paruh eliminasi 2-5 hari. $^{18}$

Tabel 2. Farmakokinetik Kanabis berdasarkan Rute Pemberian ${ }^{6}$

\begin{tabular}{lll}
\hline Rute pemberian & Inhalasi & Oral \\
\hline $\begin{array}{l}\text { \% Dosis yang masuk } \\
\text { Rute sirkulasi }\end{array}$ & $\begin{array}{l}\text { 50\% (kehilangan dosis akibat pyrolysis) } \\
\text { Paru-paru menuju bronkiolus menuju } \\
\text { alveolus }\end{array}$ & $\begin{array}{l}100 \% \\
\text { Lambung menuju usus kecil menuju vena } \\
\text { portal menuju hepar }\end{array}$ \\
$\begin{array}{l}\text { Faktor lain yang } \\
\text { memengaruhi ambilan }\end{array}$ & $\begin{array}{l}\text { Durasi dan volume inhalasi } \\
\text { Metabolisme hepar }\end{array}$ & $\begin{array}{l}\text { Absorpsi (isi lambung, laju metabolik, } \\
\text { variasi genetik pada aktivitas CYP 450, } \\
\text { regulasi enzim oleh obat lain) }\end{array}$ \\
Bioavailabilitas & $2-56 \%$ & $\begin{array}{l}\text { Metabolism hepar oleh enzim CYP450 } \\
\text { Onset }\end{array}$ \\
Waktu peak plasma & Langsung & $<20 \%$ \\
Durasi & $2-10$ menit & $30-90$ menit \\
\end{tabular}

\section{Farmakodinamik}

Kanabis memiliki efek sedasi yang bila diberikan bersamaan dengan obat depresan SSP lain (seperti sedatif dan hipnotik) dapat terjadi interaksi farmakodinamik melalui potensiasi efek sentral. Penelitian pada sukarelawan sehat menunjukkan etanol dapat meningkatkan kadar THC plasma dari kanabis inhalasi. ${ }^{18}$

Penggunaan kanabis telah dikaitkan dengan toksisitas patologis dan perilaku sehingga sebaiknya tidak diberikan pada pasien dengan penyakit kejiwaan, kardiovaskular, ginjal atau hepar yang signifikan. THC menghasilkan penurunan kinerja yang tergantung dosis. Setelah dosis THC inhalasi tunggal, penurunan terbesar terjadi pada 1 jam pertama dan menurun selama 2-4 jam berikutnya. Gangguan kognitif dan psikomotor yang berat dikaitkan dengan konsentrasi THC darah lebih dari $5 \mathrm{ng} /$ $\mathrm{ml}$. Pada sukarelawan sehat, pemberian THC dapat menyebabkan gejala psikotik, mengubah persepsi, meningkatkan kecemasan, dan defisit kognitif. Selain itu, kanabinoid juga dapat menginduksi takikardia melalui efek agonis reseptor CB1 jaringan jantung. Toksisitas jantung dapat terjadi dengan pemberian amfetamin, 
kokain, atropin atau agen simpatomimetik lainnya. Pemberian CBD dapat mengurangi efek psikotropik dan kardiovaskular yang negatif akibat THC. Kanabis dengan konsentrasi THC tinggi dikaitkan dengan tingkat kecanduan yang lebih besar dibandingkan kanabis dengan THC rendah. ${ }^{18,19}$

\section{Endocannabinoid System (ECS)}

Endokanabinoid dan reseptornya dapat ditemukan di seluruh tubuh manusia, baik di sistem saraf, organ internal, jaringan ikat, kelenjar, dan sel imun. ${ }^{15}$ ECS memiliki empat komponen utama, yaitu (1) Reseptor kanabinoid G-protein coupled CB1 dan CB2, (2) Endokanabinoid endogen, (3) Enzim yang mengkatalisasi biosintesis dan metabolisme endokanabinoid, (4) Mekanisme yang terlibat dalam akumulasi sel endokanabinoid spesifik. ${ }^{4}$

Reseptor CB1 diekspresikan di otak dan jaringan perifer, namun paling banyak terdapat di otak, sehingga memediasi hampir semua efek psikoaktif THC pada kanabis. Reseptor CB1 banyak di otak kecil (kognisi, koordinasi), hipokampus (pembelajaran dan memori), korteks (fungsi kognitif, fungsi eksekutif dan kontrol, input sensorik), basal ganglia (kontrol motorik, perencanaan) ventral striatum (prediksi dan feeling of reward), amigdala (kecemasan, emosi, ketakutan), hipotalamus (nafsu makan, kadar hormon, perilaku seksual), batang otak dan sumsum tulang belakang (muntah, nyeri). ${ }^{4}$

Reseptor CB2 ditemukan terutama di perifer, pada sel-sel imun, dan sistem hematopoietik. Reseptor CB2 juga diekspresikan di otak dan memodulasi pelepasan sinyal kimia terutama yang terlibat dalam fungsi sistem kekebalan tubuh (misalnya. sitokin). Reseptor CB2 dapat menghilangkan semua efek psikoaktif THC pada manusia oleh antagonisme selektif dari reseptor CB1, sehingga aktivasi THC terhadap CB2 tidak menghasilkan efek psikoaktif. Dengan demikian, reseptor CB2 adalah target potensial untuk terapi karena dapat menghindari efek samping yang disebabkan oleh kanabis atau THC melalui reseptor CB1. ${ }^{4}$

Dua ligan utama untuk reseptor endokanabinoid adalah $\mathrm{N}$-arachidonoyl-ethanolamine (dikenal sebagai anandamida/AEA) dan 2-arachidonylglycerol (2-AG).20 Sintesis endokanabinoid dimulai dengan aktivasi reseptor glutamat yang mengaktifkan pemecahan diasilgliserol menjadi 2-AG. Endokanabinoid ini diangkut secara retrograd kecelahsinaptikdimanaiamengaktifkan reseptor CB1 pra-sinaptik. AEA disintesis dari $\mathrm{N}$-arachidonoyl phosphatidylethanolamine (NAPE) melalui beberapa fosfolipase. 2-AG dan AEA memiliki transporter endokanabinoid yang memfasilitasi reuptake dan degradasi berikutnya. 2-AG terdegradasi dalam neuron pra-sinaptik oleh monoacylglycerol lipase (MAG lipase) menjadi asam arakidonat dan gliserol. AEA dipecah secara pasca-sinaptik oleh fatty acid amino hydrolase (FAAH) menjadi asam arakidonat dan etanolamin, yang selanjutnya mengaktifkan transient receptor potential channel 1 (TRPV1). ${ }^{20}$

Efek AEA dan 2-AG dapat ditingkatkan dengan "entourage compounds" yang menghambat hidrolisis melalui kompetisi substrat sehingga memperpanjang kerjanya melalui sinergi dan augmentasi. Entourage compounds termasuk N-palmitylethanolamide (PEA), $\mathrm{N}$-oleoylethanolamide (SEA), dan cis-9octadecenoamide (OEA atau oleamide). ${ }^{15}$

\section{Fungsi sistem endocannabinoid di otak}

Perkembangan otak, neurogenesis, gangguan kejiwaan

Pengiriman sinyal endokanabinoid sangat penting untuk perkembangan otak, kelangsungan hidup dan proliferasi sel punca saraf, serta motilitas dan diferensiasi sel neuronal dan glial. Endokanabinoid berkontribusi pada penyakit neuropsikiatri seperti autisme, skizofrenia, gangguan bipolar, dan depresi. ${ }^{15}$

\section{Neuroprotektif}

Kanabinoid beserta reseptor CB1 dan CB2 memiliki efek neuroprotektif di otak dengan mencegah atau mengurangi keparahan kerusakan yang diakibatkan oleh cedera mekanik, aliran darah, atau bentuk cedera lainnya. Ablasi genetik reseptor CB1 dapat memperberat stroke iskemik. Agonis CB2 memberikan sifat anti-inflamatorik dan aktivasi CB1 memicu hipotermia. ${ }^{15}$

Fungsi sensorik (penciuman, pendengaran, nyeri)

Sistem endokanabinoid berkontribusi terhadap sensasi penciuman, pendengaran, dan nyeri. ${ }^{15}$ 


\section{Nafsu makan dan mual}

Sejumlah nukleus di medula terlibat dalam regulasi nafsu makan dan mual. Nukleus ini mengkoordinasikan input sensorik dari batang otak, kompleks vagal, organ vestibular, dan organ perifer. Endokanabinoid dan agonis CB1 menghambat serabut vagal untuk meningkatkan nafsu makan, sedangkan antagonis CB1 mengurangi nafsu makan. ${ }^{15}$

\section{Tidur}

Kanabinoid endogen dan eksogen, termasuk kanabis dan THC, memengaruhi pola tidur. Kanabis atau kanabinoid telah dilaporkan memiliki manfaat terapeutik pada gangguan tidur. ${ }^{15}$

\section{Gangguan afektif}

Sistem endokanabinoid memiliki efek perbaikan mood, anti-depresi, dan ansiolitik. Respons ansiolitik terhadap kanabis bersifat bifasik, yang menunjukkan bahwa dosis kanabis merupakan faktor penting dalam mengurangi risiko kecemasan dan depresi. Kanabis dosis tinggi meningkatkan risiko depresi atau kecemasan, mungkin dengan menurunkan reseptor CB1. ${ }^{15}$

\section{Aktivitas kejang}

Sistem kanabinoid endogen meningkatkan ambang kejang. Oleh karena itu, tidak mengherankan bahwa kanabis eksogen memiliki aktivitas anti kejang. Jika kanabis dosis tinggi dikonsumsi oleh individu dengan ambang kejang yang rendah, kanabis justru dapat meningkatkan kejang. CBD memiliki potensi terapeutik sebagai obat antiepilepsi tanpa efek psikoaktif. ${ }^{15}$

\section{Fungsi motorik}

Sistem endokanabinoid memiliki peran kompleks dalam mengatur jaras motorik yang mungkin berhubungan dengan pengurangan gejala atau berkontribusi terhadap patologi yang ditandai dengan gangguan motorik. Reseptor CB1 banyak ditemukan di daerah otak yang mengatur fungsi motorik dan koordinasi, termasuk basal ganglia dan otak kecil. Reseptor CB1 mengalami penurunan regulasi dalam beberapa kondisi neurologis. ${ }^{15}$

\section{Fungsi kognitif}

Kanabinoid dapat memfasilitasi dan menurunkan proses pembelajaran. Kanabis menurunkan daya ingat yang mungkin disebabkan oleh mekanisme kerja di hipokampus yang merupakan wilayah otak untuk pembelajaran dan daya ingat. Gangguan ini dapat terjadi akibat penekanan pelepasan glutamat di hipokampus sehingga terbentuk plastisitas sinaptik. ${ }^{15}$

\section{Fungsi sistem endocannabinoid di jaringan perifer}

\section{Saluran cerna}

Reseptor CB1 dan CB2 sangat diekspresikan pada saraf enterik dan pada sel enteroendokrin (CB2) di seluruh mukosa usus, pada sel imun (CB1 dan CB2), dan enterosit (CB1 dan CB2). Beberapa fungsi metabolik dan homeostasis usus diatur oleh endokanabinoid.

\section{Sistem kardiovaskular}

CB1, CB2, endokanabinoid dan enzimnya ditemukan di jaringan kardiovaskular dan dapat berkontribusi pada perkembangan gangguan kardiovaskular. Efek akut kanabis adalah takikardia ringan dengan peningkatan curah jantung dan peningkatan kebutuhan oksigen otot jantung.

\section{Hepar}

Ekspresi reseptor kanabinoid biasanya rendah di hepar, dan reseptor CB1 dan CB2 memiliki mekanisme kerja yang berlawanan. Reseptor CB2 memediasi beberapa fungsi biologis dalam berbagai jenis sel hepar, dan blokade CB1 berkontribusi terhadap efek metabolik yang positif. Ekspresi CB1 meningkat dalam keadaan patologis, meningkatkan fibrogenesis, steatosis, dan komplikasi kardiovaskular akibat penyakit hepar. Sebaliknya, CB2 bersifat protektif dan mengurangi indeks disfungsi hepar.

\section{Sistem imun}

Endokanabinoid memodulasi aktivitas fungsional sel imun, sebagian besar melalui reseptor CB2.

\section{Otot}

Pengiriman sinyal endokanabinoid (sebagian besar melalui reseptor CB2) berkontribusi untuk mengatur metabolisme energi dalam otot dan 
pembentukan serat otot baru.

\section{Sistem reproduksi}

Pengiriman sinyal endokanabinoid, terutama dimediasi oleh reseptor CB2, mengatur semua tahap penting kehamilan dan memengaruhi kejadian selama kehamilan. Pengiriman sinyal endokanabinoid juga terlibat dalam menjaga fungsi sperma normal.

\section{Kulit}

Pengiriman sinyal endokanabinoid melalui CB1 dan CB2 terlibat dalam regulasi fungsi kulit seperti proliferasi, diferensiasi, kelangsungan hidup sel, respons imun dan menekan peradangan kulit.

\section{Organ lain}

Peran pengiriman sinyal endokanabinoid dalam saluran pernapasan dan sistem urin masih belum jelas, tetapi terdapat evidence bahwa reseptor CB1 dan CB2 dapat berkontribusi pada penyakit ginjal.

\section{Interaksi Obat}

Uji klinis terkait efek kanabinoid eksogen terhadap metabolisme obat lain masih terbatas. Pemberian ketokonazol bersamaan dengan ekstrak kanabis oromukosal yang mengandung THC dan CBD dapat meningkatkan konsentrasi serum maksimum THC (1,2 kali lipat) dan CBD (2 kali lipat). Pemberian rifampisin dapat menyebabkan penurunan kadar THC dan CBD. Dronabinol tidak dikaitkan dengan interaksi obat yang signifikan secara klinis meskipun efek farmakodinamik aditif dapat terjadi ketika digunakan bersama dengan agen lain yang memiliki efek fisiologis yang serupa. Selain itu, kanabis dapat meningkatkan metabolisme teofilin. ${ }^{15}$

\section{Kontraindikasi}

Kanabis umumnya tidak diberikan pada wanita hamil dan menyusui, pasien dengan psikosis (kecuali sediaan dominan CBD). Kanabis harus digunakan dengan hati-hati pada pasien dengan kondisi jantung tidak stabil (seperti angina) karena dapat menyebabkan takikardia dan hipotensi akibat THC. Penggunaan kanabis pada anak-anak dan remaja tetap menjadi perdebatan karena dapat menyebabkan kecanduan dan ketergantungan. ${ }^{13}$

\section{Dosis}

Efek THC sediaan oral lebih mudah diprediksi karena konsentrasinya telah disediakan oleh produsen, sedangkan efek vaporisasi lebih sulit. Hal tersebut terjadi karena adanya variabel yang dapat memengaruhi dosis seperti ukuran ruang, kedalaman inhalasi, dan konsentrasi THC dalam chemovar. Idealnya, pasien mulai menggunakan sediaan yang kandungan THC lebih dominan pada waktu tidur untuk mengurangi efek samping dan pengembangan toleransi. ${ }^{13}$

- Hari 1-2: ekuivalen THC 2,5 mg pada waktu tidur (dapat dimulai pada 1,25 mg pada usia muda, usia lanjut, atau masalah lain).

- Hari 3-4: jika dosis sebelumnya dapat ditoleransi, naikkan dosis THC sebesar 1,252,5 mg sebelum tidur.

- Hari 5-6: tingkatkan dosis THC sebesar 1,252,5 $\mathrm{mg}$ sebelum tidur setiap 2 hari hingga tercapai efek yang diinginkan. Jika terjadi efek samping, kurangi dosis hingga dosis yang paling ditoleransi sebelumnya.

Beberapa pasien memerlukan THC untuk siang hari tergantung pada gejalanya. Pertimbangkan penggunaan chemovar kecuali hasil yang ingin dicapai adalah sedasi. Sebagian besar pasien memerlukan dosis oral 2-3 kali sehari, sehingga regimen berikut dapat dipertimbangkan: ${ }^{13}$

- Hari 1-2: ekuivalen THC 2,5 mg sekali sehari

- Hari 3-4: THC 2,5 mg dua kali sehari

- Tingkatkan sesuai kebutuhan dan toleransi menjadi ekuivalen THC 15 mg dibagi menjadi 2-3 kali sehari

- Dosis melebihi 20-30 mg/hari dapat meningkatkan efek samping atau menyebabkan toleransi tanpa meningkatkan efikasi.

Chemovar yang lebih dominan CBD menghasilkan efek samping lebih sedikit, tetapi belum pedoman untuk maksimum kecuali pada kasus psikosis (800 mg) dan gangguan kejang (2.500 $\mathrm{mg}$ atau $25-50 \mathrm{mg} / \mathrm{kg}$ ). Untuk indikasi lain, beberapa pasien dapat diobati dengan dosis yang jauh lebih rendah, dimulai dengan sediaan oral 5-20 mg per hari dibagi menjadi 2-3 kali sehari. ${ }^{13}$

\section{Peran Kanabis dalam Penanganan Nyeri Kronis}

Sel-sel saraf dan non-saraf pada jaringan yang terluka menghasilkan turunan asam arakidonat 
yang disebut endokanabinoid. Endokanabinoid memodulasi konduksi sinyal nyeri dengan mengurangi sensitisasi dan peradangan melalui aktivasi reseptor kanabinoid yang menjadi target D9THC. Reseptor CB1 memodulasi pelepasan neurotransmiter di otak dan medulla spinalis. Reseptor CB1 ditemukan pada neuron sensorik nosiseptif dan non-nosiseptif di dorsal root ganglion dan ganglion trigeminal, serta pada sel makrofag, sel mast, dan keratinosit epidermal. Reseptor CB2 diekspresikan di otak, medulla spinalis, dan dorsal root ganglion. Reseptor ini meningkat sebagai respons terhadap kerusakan saraf perifer. Reseptor ini mengatur interaksi neuroimun dan memodulasi hiperalgesia inflamatorik. 7,21

Selain endokanabinoid, AEA dan 2-AG juga diproduksi di jaringan yang mengalami cedera melalui jalur biokimia yang berbeda untuk menekan sensitisasi dan peradangan dengan mengaktifkan reseptor kanabinoid. AEA dapat bekerja sebagai autocrine/paracrine messenger. Dalam reaksi yang dikatalisis oleh fatty acid amide hydrolase, AEA dapat dipecah menjadi asam arakidonat dan etanolamin atau langsung diubah oleh COX-2 menjadi proalgesic prostamides. AEA berespons terhadap peradangan dan cedera saraf dan memodulasi sinyal nosiseptif dengan mengaktifkan reseptor CB1 lokal. 2-AG dibentuk oleh hidrolisis phosphatidylinositol4,5-biphosphate, yaitu fosfolipid di pusat jalur jaras lipid yang menghasilkan banyak messenger intraseluler dan transelular. 2-AG berperan penting dalam menurunkan nyeri selama stres akut. AEA dan 2-AG direkrut selama cedera jaringan untuk memberikan respons terhadap sinyal nosiseptif. ${ }^{7}$

Sejumlah penelitian telah mengevaluasi kanabinoid untuk nyeri nosiseptif, muskuloskeletal, dan inflamatorik. ${ }^{22}$ Sebuah studi dengan dronabinol pada nyeri kronis nonkanker menemukan bahwa dosis tunggal harian 10 dan 20 mg dapat menurunkan nyeri. Studi lain pada pasien rheumatoid artritis menunjukkan bahwa nabiximols mengurangi rasa nyeri saat gerakan dan saat istirahat secara signifikan, dan peningkatan kualitas tidur dibandingkan dengan plasebo. Namun, nabiximol tidak mengurangi rigiditas di pagi hari. ${ }^{2}$

Kanabinoid lebih efektif jika digunakan untuk mengobati nyeri neuropatik kronis. Produk kanabinoid memiliki sejarah penggunaan yang lebih lama pada populasi kanker sebagai adjuvant untuk mual dan muntah akibat kemoterapi. Beberapa penelitian dronabinol oral menunjukkan bahwa obat ini efektif untuk menangani nyeri kanker pada dosis yang lebih tinggi (15-20 mg) dengan efikasi yang serupa dengan kodein (60-120 mg), tetapi dengan efek samping yang lebih signifikan. ${ }^{2}$

Studi yang dilakukan oleh Poli dkk. terhadap nyeri kanker menemukan pemberian kanabinoid mengurangi intensitas nyeri secara signifikan hingga 12 bulan follow up $(P<0,001)$ serta mengurangi gejala kecemasan dan depresi $(P$ $<0,001) \cdot{ }^{23}$ Haroutounian dkk. (2016) melaporkan penggunaan kanabinoid pada 274 subjek menurunkan skor nyeri secara signifikan ( $P$

Tabel 2. Farmakokinetik Kanabis berdasarkan Rute Pemberian ${ }^{6}$

\begin{tabular}{|c|c|c|c|c|c|}
\hline Indikasi & $\begin{array}{l}\text { Jumlah studi } \\
\text { (partisipan) }\end{array}$ & $\begin{array}{l}\text { Produk } \\
\text { yang diteliti }\end{array}$ & Perbandingan & Keluaran & $\begin{array}{l}\text { Ringkasan (interval } \\
\text { kepercayaan 95\%) }\end{array}$ \\
\hline Nyeri kronis & $9(1734)$ & $\begin{array}{l}\text { Sativex (THC } \\
+ \text { CBD) }\end{array}$ & Plasebo & $\begin{array}{l}\text { Pengurangan } \\
\text { nyeri } 30 \%\end{array}$ & $\begin{array}{l}\text { Odds ratio: } 1.46 \\
(1.16-1.84) . \text { Lebih } \\
\text { efektif dari plasebo. }\end{array}$ \\
\hline $\begin{array}{l}\text { Sklerosis } \\
\text { multipel }\end{array}$ & 5 (1244) & $\begin{array}{l}\text { Sativex (THC } \\
+ \text { CBD) }\end{array}$ & Plasebo & $\begin{array}{l}\text { Ashworth } \\
\text { spasticity scale }\end{array}$ & $\begin{array}{l}\text { Weighted mean } \\
\text { difference: }-0.12 \\
(-0.24-0.01) \text {. Tidak } \\
\text { lebih efektif than } \\
\text { plasebo. }\end{array}$ \\
\hline $\begin{array}{l}\text { Epilepsi } \\
\text { resisten obat }\end{array}$ & $2(291)$ & $\begin{array}{l}\text { Epidiolex } \\
\text { (CBD) }\end{array}$ & Plasebo & $\begin{array}{l}\text { Pengurangan } \\
\text { frekuensi } \\
\text { kejang 50\% }\end{array}$ & $\begin{array}{l}\text { Risiko relatif } 1.74 \\
(1.24-2.43) \text {. Lebih } \\
\text { efektif dari plasebo. }\end{array}$ \\
\hline $\begin{array}{l}\text { Mual dan } \\
\text { muntah akibat } \\
\text { kemoterapi }\end{array}$ & $3(102)$ & $\begin{array}{l}\text { Dronabinol } \\
\text { (THC) }\end{array}$ & Plasebo & $\begin{array}{l}\text { Respon } \\
\text { signifikan } \\
\text { terhadap mual } \\
\text { dan muntah }\end{array}$ & $\begin{array}{l}\text { Odds ratio: } 3.82 \\
\text { (1.55-9.42). Lebih } \\
\text { efektif dari plasebo. }\end{array}$ \\
\hline
\end{tabular}


$<0,001)$, disertai penurunan skor disabilitas sosial dan emosional. Konsumsi opioid pun ikut menurun hingga $44 \%(P<0,001) \cdot{ }^{24}$

\section{SIMPULAN}

Kanabis dapat menjadi pilihan pengobatan untuk menangani nyeri, terutama pada pasien yang mengalami nyeri refrakter. Beberapa efek samping potensial yang terkait penggunaan kanabis, seperti penyalahgunaan dan eksaserbasi psikotik harus mendapat perhatian secara seksama. Klinisi perlu memahami farmakologi, dosis dan rute pemberian kanabis guna memaksimalkan potensi terapeutik dan meminimalisir efek samping terkait penggunaan kanabis.

\section{DAFTAR PUSTAKA}

1. Aguilar S, Gutiérrez V, Sánchez L, Nougier M. Medicinal cannabis policies and practices around the world. Int Drug Policy Consort. 2018;32.

2. Halawa OI, Furnish TJ, Wallace MS. Role of Cannabinoids in Pain Management. Essentials Pain Med. 2018;509-520.e2.

3. Blake A, Wan BA, Malek L, DeAngelis C, Diaz $\mathrm{P}$, Lao $\mathrm{N}$, et al. A selective review of medical cannabis in cancer pain management. Ann Palliat Med. 2017;6(Suppl 2):S215-22.

4. Madras BK. Update of Cannabis and its medical use. Alcohol drug Abus Res. 2015;5(37):1-41.

5. Boggs DL, Peckham A, Boggs AA, Ranganathan M. Delta-9-tetrahydrocannabinol and cannabidiol: Separating the chemicals from the "weed," a pharmacodynamic discussion. Ment Heal Clin. 2016;6(6):277-84.

6. Nahtigal I, Blake A, Hand A, FlorentinusMefailoski A, Sohi HH, Friedberg J. The pharmacological properties of cannabis. Cannabis Med Asp. 2017:71-82.

7. Hill KP, Palastro MD, Johnson B, Ditre JW. Cannabis and Pain: A Clinical Review. Cannabis Cannabinoid Res. 2017;2(1):96104.

8. Putri DTB. Ganja di Indonesia Pola Konsumsi, Produksi, dan Kebijakan. Drug Policy Brief Transnatl Inst. 2016;44:1-24.

9. Manuel C. Pardo J, Miller RD. Chronic Pain
Management. In: Basics of ANESTHESIA. 7th ed. Philadelphia: Elsevier; 2018. p. 770-87.

10. Scholz J. Mechanisms of chronic pain. Mol Pain. 2014;10:S6-18.

11. Aronoff GM. What Do We Know About the Pathophysiology of Chronic Pain? Implications for Treatment Considerations. Med Clin North Am. 2016;100(1):31-42.

12. Iffland K, Grotenhermen F. An Update on Safety and Side Effects of Cannabidiol: A Review of Clinical Data and Relevant Animal Studies. Cannabis Cannabinoid Res. 2017;2(1):139-54.

13. MacCallum CA, Russo EB. Practical considerations in medical cannabis administration and dosing. Eur J Intern Med. 2018;49:12-9.

14. Machado Bergamaschi M, Helena Costa Queiroz R, Waldo Zuardi A, Alexandre S. Crippa J. Safety and Side Effects of Cannabidiol, a Cannabis sativa Constituent. Curr Drug Saf. 2011;6(4):237-49.

15. Bridgeman MB. Medicinal Cannabis: History, Pharmacology, And Implications for the Acute Care Setting. Pak J Pharm Sci. 2017;42(3):1-9.

16. Grotenhermen F. The pharmacokinetics and the pharmacodynamics of cannabinoids. Clin Pharmacokinet. 2003;42(4):327-60.

17. Freeman TP, Hindocha C, Green SF, Bloomfield MAP. Medicinal use of cannabis based products and cannabinoids. BMJ. 2019;365:1-7.

18. Lucas CJ, Galettis P, Schneider J. The pharmacokinetics and the pharmacodynamics of cannabinoids. $\mathrm{Br} \mathrm{J}$ Clin Pharmacol. 2018;84(11):2477-82.

19. Grotenhermen F. Clinical pharmacodynamics of cannabinoids. J Cannabis Ther. 2004;4(1):29-78.

20. Schrot RJ, Hubbard JR. Cannabinoids: Medical implications. Ann Med. 2016;48(3):128-41.

21. S. Z, A. DL, N.M. DL, G. MV. Medical use of cannabis: Italian and European legislation. Eur Rev Med Pharmacol Sci. 2018;22(4):1161-7.

22. Russo EB. Cannabinoids in the management of difficult to treat pain. Vol. 4, Therapeutics and Clinical Risk Management. 2008. p. 24559.

23. Poli P, Crestani F, Salvadori C, Valenti I, Sannino C. Medical cannabis in patients with chronic 
pain: Effect on pain relief, pain disability, and psychological aspects. A prospective non randomized single arm clinical trial. Clin Ter. 2018;169(3):E102-7.

24. Haroutounian S, Ratz Y, Ginosar Y, Furmanov K, Saifi F, Meidan R, et al. The Effect of Medicinal Cannabis on Pain and Qualityof-Life Outcomes in Chronic Pain: A Prospective Open-label Study. Clin J Pain. 2016;32(12):1036-43. 